Journal of Sustainamle Agricultural Sciences http://jsas.journals.ekb.eg/

\title{
Biocontrol Potential of Culture Filtrates of Sclerotium cepivorum Against Onion White Rot Disease
}

Nagwa M. El-Khateeb ${ }^{1}$ and H. A. Ketta ${ }^{2 *}$

${ }^{1}$ Agricultural Botany Department (Agricultural Microbiology Branch),

${ }^{2}$ Agricultural Botany Department (Plant Pathology Branch), Faculty of Agriculture,

Kafrelsheikh University, 33516, Kafrelsheikh, Egypt

$\mathbf{T}$

HE PRESENT work was purposed to investigate the efficacy of culture filtrates periodic produced by Sclerotium cepivorum in vitro $(15,30,45,60$ and 75 days) against onion white rot disease under laboratory and in vivo in the greenhouse along with how much effect on plant growth parameters. The incubation period needed for S. cepivorum to produce secondary metabolites was found as an important factor in control strategy using culture filtrate treatments. Results suggested that culture filtrates produced at different incubation periods, decreased linear growth, number and percentage of germination of well-developed sclerotia of the fungus also, increased the mean time of sclerotia onset. The least disease severity (16.67\%) was recorded with the treatment of culture filtrate 15 days old compared to infected control ( 91.67 $\%)$ and other used treatments. Sclerotia were not able to germinate with 15 days old filtrate at $100 \%$ concentration for 72 hours of soaking.Screening of secondary metabolites by gas chromatography-mass spectrophotometry (GC-MS) revealed 30 compounds categorized into alkaloids, organosilicon, antioxidants, lipids, esters, alcohols and fatty acids. Under greenhouse experiment, treatment with 15 days old culture filtrate gave the best results in reducing disease severity, improving plant growth and increasing peroxidase and polyphenol oxidase enzyme activities compared with other treatments. Secondary metabolites of S. cepivorum in 15 days old filtrate could be a powerful alternative way to chemical fungicides. Further investigations are suggested to know which metabolite compound/s responsible about control process.

Keywords: Biological control, GC-MS, Secondary metabolites, Onion, Sclerotium cepivorum, Culture filtrate, Greenhouse

\section{Introduction}

Onion (Allium cepa L.) is one of the most important crop in Egypt. Recently, Egypt considered as a top agricultural country in the region and Africa with high rank among highly producing countries of onion with cultivated area reached 162.833 feddan in 2016 producing 2 million tons with an average 14.43 ton/feddan (Yearly Book of Economics and Statistics of the Ministry of Agriculture, Egypt, 2017). White rot disease of onion caused by Sclerotium cepivorum Berk., is a very considerable economic and important disease where onion crop is cultivated over the world. Disease was firstly reported in Egypt by Nattrass (1931) in upper parts of the country.
Then the distribution of onion white rot disease in Egypt was monitored by many investigators (Abd El-Razik et al., 1973; El-Khateeb, 2004 and Hussain, 2017) through onion growing areas. The most serious problem of the disease is not only happened by direct damage of the fungus, but also through the production of sclerotia which may survive viable for many years in infested soils with or without the host plants (Entwistle, 1990). Disease control is mainly depends on chemical control strategy by effective fungicides (ColeySmith, 1970), which nowadays have a larger serious impact than before on humans, animals and beneficial microorganisms. So, the need to find some alternative approaches to the chemical

"Correspondence author: kettahammad@gmail.com 
fungicides was grown and many strategies such as crop rotation, soil solarization, plant extracts, induce resistance and biological control were applied. Under biotic (pathogenic) conditions, the defensive enzymes of host plants such as peroxidase and polyphenol oxidase could be induced through treatment by beneficial microorganisms or other elicitors to defeat or decrease the pathogen attack (Saravanakumar et al., 2007). During the control strategy of onion white rot disease, El-Khateeb (2004) stated that onion transplants treated before planting with Trichoderma lignorum, $T$. harzianum, Bacillus subtilis and B. pumilis led to high foliage fresh and dry weights in addition to a notable increase in bulb crop yield compared to that obtained using the chemical fungicide. Chemical fungicides could be minimized through the using of bacterial or fungal metabolites in controlling of various plant pathogenic bacteria or fungi. Microbial secondary metabolites could be considered as one of the promising strategies against many diseases to avoid or reduce the application of chemical fungicides. Sterilized culture filtrates of Penicillium striatisporum completely inhibited mycelium growth and sporangia/spore formation even germination of Phytophthora capsici and significantly reduced Phytophthora root rot of chilli pepper (Ma et al., 2008). Rhizoctonia solani, the causal agent of rice sheath blight was inhibited in growth and scleroltia formation when treated with Trichothecium roseum strain MML003 culture filtrate (Jayaprakashvel et al., 2010). Secondary metabolites of Bacillus chitinosporus were used effectively against Pseudoperonospora cubensis, the causal agent of cucumber downy mildew (Ketta et al., 2016). The antagonistic effect of B. chitinosporus on $P$. cubensis could be related to the fatty acids named hexadecanoic and n-hexadecanonic acid (n-C16) which are similar to the antifungal lipopeptide complex (fengycin A and B) produced by B. subtilis strain F-29-3 (Vanittanakom et al., 1986). The inhibitory effect and antimicrobial activity of fatty acids, excreted by bacterial bioagent, was reported (Skřívanová et al., 2005) but the mechanism of inhibition has not been well understood. Culture filtrate of S. cepivorum was inhibited the fungal growth of the causal agent of white rot disease of onion (Elsherbiny et al., 2015).

The present work aimed to investigate the suppression effect of culture filtrates of $S$. cepivorum under different incubation periods against white rot disease of onion through direct application to the soil of cultivated plants.

\section{Materials And Methods}

Collection and screening of S. cepivorum isolates

Several infested onion fields (clay soils with a $\mathrm{pH}$ ranged from 7.5 to 8.8 ) with $S$. cepivorum located in El-Gharbia and Kafr El-Sheikh governorates, Egypt, which have typical onion, white rot symptoms were visited and the fungus was isolated using hyphal-tip technique through obtaining sclerotia from infected bulbs according to El-Sheshtawi et al. (2009). Nine isolates of $S$. cepivorum were tested for their pathogenicity to select the most severe one. For pathogenicity testing, onion cv. Giza 20 seedlings (3/pot) were used and greenhouse conditions were controlled. Inoculum was prepared as mentioned below in the section of (Inoculum preparation and greenhouse experiments). Onion plants were uprooted after three months and half from transplanting for estimation the disease severity according to the scale of 0-100 (from yellowing the leaves till complete dead plants with decay of bulbs and roots) published by Abd El-Moity (1976) and Shatla et al. (1980) as follows:

$0 \%=$ Healthy plants, $25 \%=$ Slight severe symptoms, $50 \%=$ Moderate severe symptoms, $75 \%=$ Severe symptoms and $100 \%=$ Highly severe symptoms.

Formula described by Zewide et al. (2007) was used to calculate the disease severity:

Disease severity $\%=[$ total of all ratings / (total number of plants $\times$ maximum score) $] \times 100$

Six replicates were applied for each isolate. The isolate with the highest disease severity percentage of nine isolates was selected (No. SC. 2), identified according to cultural, microscopical and phytopathological properties specific for S. cepivorum by Mycology Laboratory, Plant Pathology Institute, Agriculture Research Center, Giza, Egypt, and used in the present study.

Incubation period for culture filtrate production

To investigate the effect of incubation periods needed for production of effective secondary metabolites from $\mathrm{S}$. cepivorum, each flasks contain $200 \mathrm{ml}$ of potato dextrose broth was inoculated by three discs of grown mycelium (identified isolate No. SC. 2). The grown mycelium discs (approx. $5 \mathrm{~mm}$ diameter) of $S$. cepivorum were obtained from one week old culture grown on potato dextrose agar medium (PDA). Inoculated flasks were incubated (BINDER) at $18 \pm 2{ }^{\circ} \mathrm{C}$ for $15,30,45,60$ and 75 days. The liquid culture 
before centrifugation at $10000 \mathrm{xg}$ for $15 \mathrm{~min}$ was filtered by Whatman filter paper No. 1 . When centrifugation finished, the supernatant was collected and filtered through $0.22 \mu \mathrm{m}$ membrane filter. Culture filtrate $(\mathrm{CF})$ was stored at $4{ }^{\circ} \mathrm{C}$ until being used in next experiments.

\section{Testing of culture filtrate in vitro}

To determine the effect of culture filtrates against $S$. cepivorum (diameter of mycelium growth), adequate volume of sterilized filtrate $5 \mathrm{ml}$ were added to $45 \mathrm{ml}$ of sterilized PDA medium (still warm before solid phase) and then poured in sterilized Petri dishes $(9 \mathrm{~cm}$ diameter). The inoculation was done according to Ismail et al. (1990) in the center of Petri dishes (containing medium) with grown mycelium discs (approximately $5 \mathrm{~mm}$ diameter) of $S$. cepivorum which obtained from one week old culture grown on PDA medium. Control treatment (normal culture media without supplementation of fungal filtrate) was concluded. Five replicates were applied for each culture filtrate taken after different incubation periods. All treatments were incubated at $18 \pm 2{ }^{\circ} \mathrm{C}$ and observed every day for evaluation. To determine the effect of culture filtrate on $S$. cepivorum, diameter of mycelial growth was measured and scored in comparison with control treatment (when the growth closed to plate edges).

Effect of culture filtrates of $S$. cepivorum at different concentrations and different incubation periods on the time required for the first formed sclerotia (days) of S. cepivorum was also investigated. Number of mature sclerotia per disc $\left(28.27 \mathrm{~mm}^{2}\right)$ after 25 days of incubation were also calculated. The ability of sclerotia to germinate after soaking in culture filtrates $(15,30,45,60$ and 75 days old) under different concentrations $(5,10,25,50$ and $100 \%)$ for 12, 24 and $72 \mathrm{hr}$ was also determined.

Inoculum preparation and greenhouse experiments

To prepare the inoculum of $\mathrm{S}$. cepivorum, healthy grains of barley were washed several times by distilled water and left $30 \mathrm{~min}$ on tissues for drying at room temperature and filled in glass bottles $500 \mathrm{ml}$ capacity in ration (100 g barley grain / $50 \mathrm{ml}$ distilled water) according to the method described by Abd El-Moity (1976). All filled bottles were closed tightly and autoclaved for $30 \mathrm{~min}$ at $121{ }^{\circ} \mathrm{C}$. Later, the bottles which filled with barley grains were inoculated by three discs (approximately $5 \mathrm{~mm}$ diameter) of grown mycelium of $S$. cepivorum (isolate No. SC. 2) obtained from one week old culture grown on PDA medium. Inoculated barley flasks were incubated at $18 \pm 2{ }^{\circ} \mathrm{C}$ for 30 days. Twenty five centimeter diameter pots were disinfected for $20 \mathrm{~min}$ using sodium hypochlorite solution ( $5 \%$ ), then rinsed by sterile distilled water and filled with sandy loam soil $(5 \mathrm{~kg})$ mixture (1:1) which autoclaved at 121 ${ }^{\circ} \mathrm{C}$ for $1 \mathrm{hr}$. was used in the present experiment. Barley grain inoculum was mixed with the upper surface of the sandy loam soil in ratio $2 \% \mathrm{w} / \mathrm{w}$. Control treatment (without barley grain inoculum) and infected control treatment were mentioned for comparison. All experiment pots were irrigated by water and left one week before transplanting. Healthy onion Giza 20 seedlings (45 days old obtained from Sakha Agriculture Research Station, Kafr El-Sheikh) were transplanted into pots (3/pot) and irrigated thoroughly by culture filtrate which produced through different incubation periods as mentioned above. Three replicates were applied for each culture filtrate taken after different incubation periods. All experiments were repeated twice. Onion plants were uprooted after three months and half from transplanting for estimation the disease severity according to the scale of 0-100 (from yellowing the leaves till complete dead plants with decay of bulbs and roots) published by Abd El-Moity (1976) and Shatla et al. (1980) as follows:

$0 \%=$ Healthy plants, $25 \%=$ Slight severe symptoms, $50 \%=$ Moderate severe symptoms, $75 \%=$ Severe symptoms and $100 \%=$ Highly severe symptoms.

Formula described by Zewide et al. (2007) was used to calculate the disease severity:

Disease severity $\%=$ [total of all ratings $/$ (total number of plants $\times$ maximum score) $] \times 100$

\section{Plant growth parameters}

Growth parameters such as plant height $(\mathrm{cm})$, root length $(\mathrm{cm})$ and bulb perimeter were measured on the same plants of greenhouse experiment mentioned above after 90 days from transplanting for treated and untreated plants. Consequently, onion leaves of treated and untreated plants were estimated for chlorophyll (Chl.) $a$ and $b$ contents after 60 days from transplanting according to the methods described by Moran (1982). One gram of fresh leaves of treated and untreated plants was immersed in $5 \mathrm{ml} \mathrm{N}$,N-dimethylformamide and kept in dark overnight at $5{ }^{\circ} \mathrm{C}$. Estimation of chlorophyll $a$ and $b$ was done using spectrophotometer (UV-160A, Shimadzu, Japan) and the absorbance was measured under 647 and $664 \mathrm{~nm}$. Chlorophyll a and b concentrations were 
calculated according to the following equations:

Chl. $\mathrm{a}=12.46 \mathrm{~A}_{664}-2.49 \mathrm{~A}_{647}(\mathrm{mg} / \mathrm{g}$ fresh weight)

Chl. $b=23.26 A_{647}-5.62 A_{664}(\mathrm{mg} / g$ fresh weight), where $\mathrm{A}=$ absorbance

Additionally, dry matter (gm) were determined by drying of weighted fresh samples of onion leaves and bulbs at $70{ }^{\circ} \mathrm{C}$ till weight stability. All samples were allowed to accept the room temperature before measuring the weight again. Initial weight and final weight were recorded and the dry matter were calculated as a differences between initial and final weights.

\section{Enzyme activity}

To estimate the enzyme activity, samples were prepared (60 days after planting) according to methods described by Maxwell and Bateman (1967). Half gram fresh weight of onion leaves were cleaned and homogenized using mortar and pestle in presence of liquid nitrogen. Obtained fine powder was gently mixed with $3 \mathrm{ml}$ of sodium phosphate buffer $(0.01 \mathrm{M}) \mathrm{pH} 6.8(1.32 \mathrm{ml}$ of $\mathrm{Na}_{2} \mathrm{HPO}_{4} \cdot 2 \mathrm{H}_{2} \mathrm{O}+1.69 \mathrm{ml}$ of $\mathrm{NaH}_{2} \mathrm{PO}_{4} \cdot \mathrm{H}_{2} \mathrm{O}$ ). Then extracted sap was filtered through cheese cloth and centrifuged at $10000 \mathrm{xg}$ for $15 \mathrm{~min}$ at $6{ }^{\circ} \mathrm{C}$. Supernatant was collected and used next as enzyme source.

\section{Peroxidase assay}

Methods described by Srivastava (1987) were used for determination of peroxidase enzyme activity via measuring the oxidation of pyrogallol to pyrogallin in presence of $\mathrm{H}_{2} \mathrm{O}_{2}$. For measuring the peroxidase activity, spectrophotometer cuvette was filled with $3 \mathrm{ml}(0.3 \mathrm{ml}$ enzyme extract source $+0.5 \mathrm{ml}$ of $0.1 \mathrm{M}$ sodium phosphate buffer $\mathrm{pH}$ $7+0.3 \mathrm{ml}$ of $0.05 \mathrm{M}$ pyrogallol $+0.1 \mathrm{ml} \mathrm{H}_{2} \mathrm{O}_{2}$ $10 \%+$ distilled water). Changes in absorbance (Optical Density OD/min/0.5g fresh weight) at $425 \mathrm{~nm}$ (spectrophotometer UV-160A, Shimadzu, Japan) with intervals $0,1,2$ and 3 minutes were recorded and calculated to indicate the peroxidase enzyme activity. Three replicates were used for each treatment. Chemical reagents without the enzyme extract source were served as a blank used for calibration.

\section{Polyphenoloxidase assay}

Methods adopted by Matta and Dimond (1963) were used for determination of polyphenoloxidase enzyme activity. For measuring the polyphenoloxidase activity, spectrophotometer cuvette was filled with $6 \mathrm{ml}$ (1 $\mathrm{ml}$ of enzyme extract source $+1 \mathrm{ml}$ of $0.2 \mathrm{M}$ sodium phosphate buffer $\mathrm{pH} 7+1 \mathrm{ml}$ of $10^{-3} \mathrm{M}$ catechol $+3 \mathrm{ml}$ distilled water). Changes in absorbance (Optical Density OD/min $/ 0.5 \mathrm{~g}$ fresh weight) at $495 \mathrm{~nm}$ (spectrophotometer UV-160A, Shimadzu, Japan) with intervals $0,1,2$ and 3 minutes were recorded and calculated to indicate the polyphenoloxidase enzyme activity. Three replicates were used for each treatment. Chemical reagents without the enzyme extract source were served as a blank used for calibration.

Gas chromatography-mass spectrophotometry identification

Gas chromatography-mass spectrophotometry (GC-MS) analysis for identification of $S$. cepivorum metabolites was carried out using an equipment (HP6890N Gas chromatography). The liquid culture filtrate of $S$. cepivorum obtained after incubation period of 150 days (filtered as mentioned above in the section of culture filtrate production) was centrifuged at $10000 \mathrm{xg}$ for 20 min. For pellets collection, obtained supernatant was centrifuged again at $15000 \mathrm{xg}$ for $20 \mathrm{~min}$ after adjustment $\mathrm{pH}$ to 2.5 using $\mathrm{HCl}$ according to methods of McKeen et al. (1986). Collected pellets washed twice with $80 \%$ ethanol and then left to dry. Small volume of ethanol $80 \%$ were added to the dried pellets for dissolving it with gentle mix by hands and stored at $4{ }^{\circ} \mathrm{C}$ for further usage. Dissolved pellets were diluted and injected into the gas chromatography (HP 6890N) equipped with mass detector (HP 5975) and a capillary column of fused silica HP 5-MS (30 m $\times 0.32 \mathrm{~mm}$ with film thickness $0.25 \mu \mathrm{m})$. The programmed oven temperature was gradually raised at a rate of $30^{\circ} \mathrm{C}$ per min until $230^{\circ} \mathrm{C}$ and then maintained for $20 \mathrm{~min}$ at $230^{\circ} \mathrm{C}$. The detector was heated and injection port was $250^{\circ} \mathrm{C}$. The carrier gas used was helium at 5 Psi pressure. The mass spectra were obtained by the parameters of ionization potential $70 \mathrm{eV}$, a temperature $250^{\circ} \mathrm{C}$ and mass range from 40-420. The identification of metabolites was based on their retention times and mass spectra compared to those compounds in the database library of NIST 98 L, Wiley 7n1 and Pest 1 by Chemstation Integrator computer software.

\section{Statistical analysis}

All experiments were designed as randomized complete with factorial arrangement. Analysis of variance (ANOVA) after data transformation was carried out by Costat software. Means were compared using Duncan multiple range test DMRT (Duncan, 1955). 


\section{$\underline{\text { Results and Discussion }}$}

Isolates of S. cepivorum

Pathogenicity test of nine isolates of $S$. cepivorum showed that, isolate No. SC. 2 was the most aggressive one on onion cv. Giza 20 plants. Isolate No. SC. 2 gave $91.67 \%$ of disease severity, while isolate No. SC. 3 gave the least percentage $41.67 \%$ (Table 1).

Effect of culture filtrate In vitro

Onion white rot disease caused by S. cepivorum, is one of the most destructive soil-borne pathogens that pose significant threat to production of onion and other Allium species in all over the world. In the present study, effect of $S$. cepivorum culture filtrates at different incubation periods $(15,30$,
45, 60 and 75 day) and concentrations (5, 10 and $25 \%$ ) on linear growth of onion white rot pathogen was investigated. Obtained results revealed that culture filtrate under $25 \%$ concentration was more effective than other used concentrations on linear growth of the studied fungus (Table 2 and Fig. 1). Otherwise, significant differences were recorded either between used treatments each other or control treatment (treated by sterilized water). The most significantly effective treatment was T5 (treated with culture filtrate 15 days old), which gave the least value of linear growth $(4.17,3.53$ and $2.30 \mathrm{~cm}$ ) under concentrations 5,10 and $25 \%$, respectively compared to other used treatments (Table 2 and Fig. 1).

TABLE 1. Disease severity (\%) of nine $S$. cepivorum isolates on onion cv. Giza 20 transplants

\begin{tabular}{c|c}
\hline Isolate & Disease severity (\%) \\
\hline SC1 & $83.33 \mathrm{c}$ \\
SC2 & $91.67 \mathrm{a}$ \\
SC3 & $41.67 \mathrm{i}$ \\
SC4 & $87.50 \mathrm{~b}$ \\
SC5 & $66.67 \mathrm{f}$ \\
SC6 & $54.17 \mathrm{~g}$ \\
SC7 & $70.83 \mathrm{e}$ \\
SC8 & $45.83 \mathrm{~h}$ \\
SC9 & $79.17 \mathrm{~d}$ \\
\hline
\end{tabular}
at 0.05 level. $\mathrm{SC}=$ S. cepivorum.

TABLE 2. Effect of culture filtrates of $S$. cepivorum at different incubation periods and concentrations on linear growth of $S$. cepivorum

\begin{tabular}{cccc}
\hline \multirow{2}{*}{ Treatment* } & \multicolumn{2}{c}{$\begin{array}{c}\text { Linear growth (cm) } \\
\text { Culture filtrate concentration (v/v) }\end{array}$} \\
\hline Control treatment & $\mathbf{5 \%}$ & $\mathbf{1 0 \%}$ & $\mathbf{2 5 \%}$ \\
T1 & $8.77 \mathrm{a}$ & $8.47 \mathrm{a}$ & $8.23 \mathrm{a}$ \\
T2 & $8.17 \mathrm{a}$ & $7.70 \mathrm{~b}$ & $7.13 \mathrm{~b}$ \\
T3 & $7.23 \mathrm{~b}$ & $6.27 \mathrm{c}$ & $5.73 \mathrm{c}$ \\
T4 & $6.10 \mathrm{c}$ & $5.43 \mathrm{~d}$ & $4.83 \mathrm{~d}$ \\
T5 & $5.47 \mathrm{~d}$ & $4.17 \mathrm{e}$ & $3.57 \mathrm{e}$ \\
\hline
\end{tabular}

The numbers in the same column (means) followed by the same letter are not significantly different according to DMRT at 0.05 level.

*Control (water treated control), T1 (CF 75 days old), T2 (CF 60 days old), T3 (CF 45 days old), T4 (CF 35 days old) and T5 (CF 15 days old). 


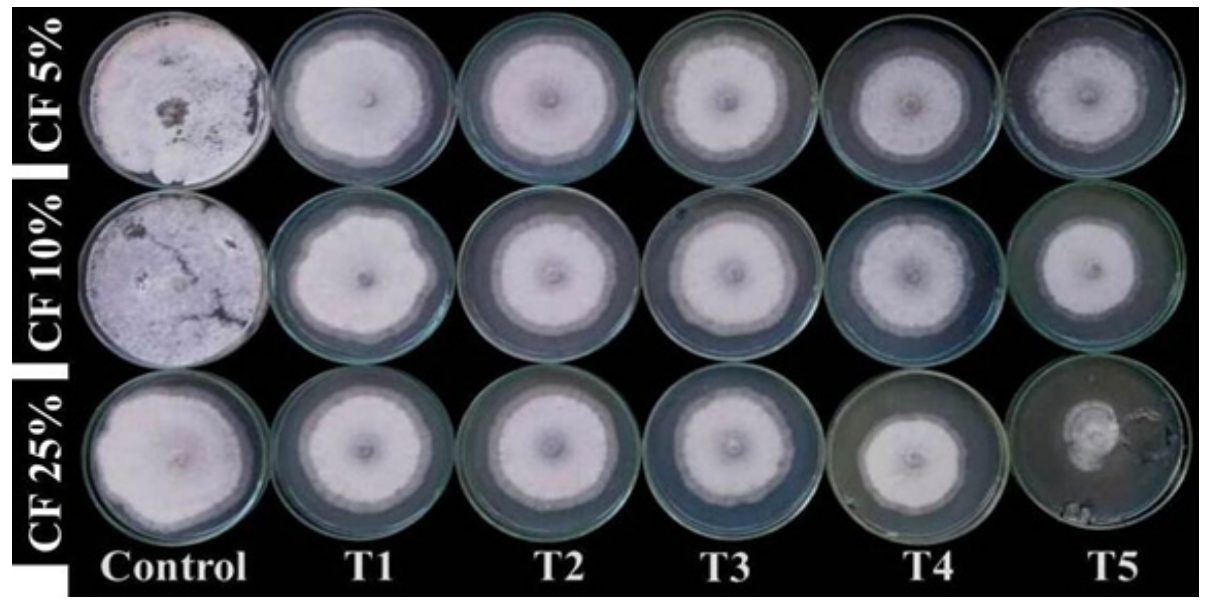

Fig. 1. Effect of culture filtrates (CF) of $S$. cepivorum at different concentrations $(5,10$ and $25 \%)$ and incubation periods on linear growth of $S$. cepivorum, where: Control (water treated control), T1 (CF 75 days old), T2 (CF 60 days old), T3 (CF 45 days old), T4 (CF 30 days old) and T5 (CF 15 days old)

Effect of culture filtrates of $\mathrm{S}$. cepivorum at different concentrations and different incubation periods $(15,30,45,60$ and 75 days old $)$ on the time required for the first formed sclerotia (days) of $\boldsymbol{S}$. cepivorum was also investigated. Data summarized in Table 3 indicated that the most significantly effective treatment was T5 (treated with culture filtrate 15 days old), which gave the least value of days required for first formed sclerotia (17.33, 19.33 and 25.33 days) under concentrations 5, 10 and $25 \%$, respectively compared with other used treatments (Table 3). Obtained results established that the efficacy of culture filtrates of $\boldsymbol{S}$. cepivorum at incubation period of 15 days was significantly higher than other concentrations of the same treatment to delay the formation of sclerotia.
Obtained results established that culture filtrates of $S$. cepivorum at concentration $25 \%$ produced under incubation period of 15 days inhibit the first formation of $S$. cepivorum' sclerotia in vitro.

Number of mature sclerotia per disc (28.27 $\mathrm{mm}^{2}$ ) after 25 days of incubation was also investigated and calculated. Significant differences were found between all used treatments on the number of mature sclerotia per disc $\left(28.27 \mathrm{~mm}^{2}\right)$ after 25 days of incubation (Table 4). The most significant results were found with the treatment T5 (treated with culture filtrate 15 days old), which gave the least value of mature sclerotia number per disc (14.00, 10.00 and 2.66 sclerotia per disc) under concentrations 5,10 and $25 \%$, respectively compared with other used treatments (Table 4).

TABLE 3. Effect of culture filtrates of $S$. cepivorum at different incubation periods and concentrations on the time required for the first formed sclerotia (days) of $S$. cepivorum

\begin{tabular}{cccc}
\hline & \multicolumn{3}{c}{ The mean time required for the first formed sclerotia (days) } \\
\cline { 2 - 4 } Treatment* & \multicolumn{2}{c}{ Culture filtrate concentration $(\mathbf{v} / \mathbf{v})$} \\
& $\mathbf{5 \%}$ & $\mathbf{1 0 \%}$ & $\mathbf{2 5 \%}$ \\
\hline Control treatment & $9.00 \mathrm{e}$ & $9.00 \mathrm{f}$ & $9.00 \mathrm{e}$ \\
T1 & $9.67 \mathrm{e}$ & $11.33 \mathrm{e}$ & $13.33 \mathrm{~d}$ \\
$\mathrm{~T} 2$ & $13.33 \mathrm{~d}$ & $14.33 \mathrm{~d}$ & $16.33 \mathrm{c}$ \\
$\mathrm{T} 3$ & $14.33 \mathrm{c}$ & $15.67 \mathrm{c}$ & $17.00 \mathrm{c}$ \\
$\mathrm{T} 4$ & $15.33 \mathrm{~b}$ & $16.67 \mathrm{~b}$ & $18.33 \mathrm{~b}$ \\
T5 & $17.33 \mathrm{a}$ & $19.33 \mathrm{a}$ & $25.33 \mathrm{a}$ \\
\hline
\end{tabular}

The number in the same column means followed by the same letter are not significantly different according to DMRT at 0.05 level.

*Control (water treated control), T1 (CF 75 days old), T2 (CF 60 days old), T3 (CF 45 days old), T4 (CF 30 days old) and T5 (CF 15 days old).

J. Sus. Agric. Sci. 45, No. 4 (2019) 
TABLE 4. Effect of culture filtrates of $S$. cepivorum at different concentrations on number of mature sclerotia per disc $(28.27 \mathrm{~mm} 2)$ on 25 days of $S$. cepivorum

Number of mature sclerotia per disc $\left(28.27 \mathrm{~mm}^{2}\right)$ on 25 days

Treatment*

Culture filtrate concentration (v/v)

\begin{tabular}{cccc} 
& $\mathbf{5 \%}$ & $\mathbf{1 0 \%}$ & $\mathbf{2 5 \%}$ \\
\hline Control treatment & $42.33 \mathrm{a}$ & $40.33 \mathrm{a}$ & $38.67 \mathrm{a}$ \\
T1 & $38.67 \mathrm{~b}$ & $30.67 \mathrm{~b}$ & $27.33 \mathrm{~b}$ \\
T2 & $28.33 \mathrm{c}$ & $23.67 \mathrm{c}$ & $20.33 \mathrm{c}$ \\
T3 & $23.00 \mathrm{~d}$ & $19.00 \mathrm{~d}$ & $14.67 \mathrm{~d}$ \\
T4 & $17.00 \mathrm{e}$ & $13.33 \mathrm{e}$ & $9.67 \mathrm{e}$ \\
T5 & $14.00 \mathrm{f}$ & $10.00 \mathrm{f}$ & $2.66 \mathrm{f}$ \\
\hline
\end{tabular}

The number in the same column means followed by the same letter are not significantly different according to DMRT at 0.05 level.

*Control (water treated control), T1 (CF 75 days old), T2 (CF 60 days old), T3 (CF 45 days old), T4 (CF 30 days old) and T5 (CF 15 days old).

The ability of sclerotia to germinate after soaking in culture filtrates $(15,30,45,60$ and 75 days old) for 12, 24 and $72 \mathrm{hr}$ was determined. Data presented in Table 5 shows that there were significant differences between all used concentrations and incubation periods on the ability of $S$. cepivorum sclerotia to germinate after 12, 24 and $72 \mathrm{hr}$. Most significant results were obtained with the treatment T5 (treated with culture filtrate 15 days old), which gave the least value of sclerotia ability to germinate $(23.33,6.67$ and 0.00 germinated sclerotia) after soaking in culture filtrate for 12,24 and $72 \mathrm{hr}$ under culture filtrate concentration $100 \%$, compared with other used treatments under different concentrations (Table 5).

Secondary metabolites as a fungitoxic compounds produced by $S$. cepivorum were not well studied or described through previous literature. However, conducted study showed that culture filtrates of $S$. cepivorum was very effective on mycelial growth, first formed sclerotia, number of mature sclerotia per disc, the ability of sclerotia to germinate after soaking for certain time, disease severity percentage as well as enhancement the growth parameters and enzymes activity. Present discussion will explain why the increment of inhibition effect of culture filtrates of $S$. cepivorum against the pathogen of onion white rot is related to the incubation time required for its production. Wiemann and Keller (2014) described that, the production of secondary metabolites needs a lot of factors such as carbon source, energy and specific enzymes through specific genes in genome. Based on the chemical structure and/or origin of biosynthesis, secondary metabolites excreted by fungi were classified into four classes (Hoffmeister \& Keller 2007 and Fox \& Howlett 2008). For example, fumonisins and aphlatoxins belonging to class (Polyketides), while, sirodesmin, penicillin and peramine belonging to class (Non-ribosomal peptides). Third class named derivatives of prenylated tryptophan contain indole alkaloids and ergot. The final group named terpenes contain deoxynivalenole (DON) and gibberellins. In addition, hybrids between these groups have been identified in different fungal species (e.g., fumagillin) (Lin et al., 2013). In the fungal genome, the genes responsible for secondary metabolite biosynthesis are found in large gene clusters (Breakspear and Momany 2017). For example 30-70 gene clusters (large amount) are responsible for secondary metabolite synthesis in filamentous fungi (Scharf et al., 2014) and some of these fungi using more than $12000-15000$ gene to produce the secondary metabolites (Yu and Keller, 2005). To produce 26 secondary metabolites by Sclerotinia sclerotiorum, there are 28 genes regulate the secondary metabolite production (Amselem et al., 2011). Furthermore, producing of non-ribosomal peptides by Trichoderma virens need 440 genes in the genome encoding 28 genes (Mukherjee et al., 2012). Fifteen gene clusters, which have been reported by Szewczyk et al. (2008) are responsible for the regulation synthesis of non-ribosomal peptides, terpenes, fatty acids, polyketides and indole 
TABLE 5. Effect of soaking sclerotia of $S$. cepivorum for different periods at different concentrations of $S$. cepivorum culture filtrate on their ability of germination

\begin{tabular}{|c|c|c|c|c|}
\hline \multirow[t]{2}{*}{ Treatment* } & \multirow{2}{*}{$\begin{array}{l}\text { Culture filtrate } \\
\text { conc. }(\%)\end{array}$} & \multicolumn{3}{|c|}{$\%$ germination after soaking (hr) } \\
\hline & & 12 & 24 & 72 \\
\hline \multirow[t]{8}{*}{ Control treatment } & 0 & $100.00 \mathrm{a}$ & $100.00 \mathrm{a}$ & $100.00 \mathrm{a}$ \\
\hline & 5 & $100.00 \mathrm{a}$ & $100.00 \mathrm{a}$ & $100.00 \mathrm{f}$ \\
\hline & 10 & $100.00 \mathrm{a}$ & $100.00 \mathrm{a}$ & $83.33 \mathrm{~b}$ \\
\hline & 25 & $100.00 \mathrm{a}$ & $91.67 \mathrm{~b}$ & $76.67 \mathrm{c}$ \\
\hline & 50 & $86.67 \mathrm{~b}$ & $80.00 \mathrm{c}$ & $61.67 \mathrm{e}$ \\
\hline & 100 & $73.33 \mathrm{~cd}$ & 66.67 ef & $51.67 \mathrm{f}$ \\
\hline & 5 & $100.00 \mathrm{a}$ & $100.00 \mathrm{a}$ & $100.00 \mathrm{a}$ \\
\hline & 10 & $100.00 \mathrm{a}$ & $66.67 \mathrm{ef}$ & $55.00 \mathrm{f}$ \\
\hline \multirow[t]{5}{*}{$\mathrm{T} 2$} & 25 & $76.67 \mathrm{c}$ & $58.33 \mathrm{~g}$ & $41.67 \mathrm{gh}$ \\
\hline & 50 & $68.33 \mathrm{~d}$ & $45.00 \mathrm{hi}$ & $35.00 \mathrm{~h}$ \\
\hline & 100 & $61.67 \mathrm{e}$ & $33.33 \mathrm{jk}$ & $26.67 \mathrm{i}$ \\
\hline & 5 & $100.00 \mathrm{a}$ & $100.00 \mathrm{a}$ & $100.00 \mathrm{a}$ \\
\hline & 10 & $100.00 \mathrm{a}$ & $71.67 \mathrm{de}$ & $45.00 \mathrm{~g}$ \\
\hline \multirow[t]{5}{*}{$\mathrm{T} 3$} & 25 & $71.67 \mathrm{~cd}$ & $50.00 \mathrm{~h}$ & $36.67 \mathrm{~h}$ \\
\hline & 50 & $58.33 \mathrm{e}$ & $41.67 \mathrm{i}$ & $26.67 \mathrm{i}$ \\
\hline & 100 & $43.33 \mathrm{fg}$ & $31.67 \mathrm{jk}$ & $20.00 \mathrm{ij}$ \\
\hline & 5 & $100.00 \mathrm{a}$ & $75.00 \mathrm{~cd}$ & $66.67 \mathrm{~d}$ \\
\hline & 10 & $68.33 \mathrm{~d}$ & $61.67 \mathrm{fg}$ & $51.67 \mathrm{f}$ \\
\hline \multirow[t]{5}{*}{$\mathrm{T} 4$} & 25 & $56.67 \mathrm{e}$ & $48.33 \mathrm{~h}$ & $38.33 \mathrm{~h}$ \\
\hline & 50 & $46.67 \mathrm{f}$ & $38.33 \mathrm{ij}$ & $26.67 \mathrm{i}$ \\
\hline & 100 & $40.00 \mathrm{~g}$ & $28.33 \mathrm{k}$ & $18.33 \mathrm{j}$ \\
\hline & 5 & $83.33 \mathrm{~b}$ & $63.33 \mathrm{fg}$ & $41.67 \mathrm{gh}$ \\
\hline & 10 & $56.67 \mathrm{e}$ & $38.33 \mathrm{ij}$ & $21.67 \mathrm{ij}$ \\
\hline \multirow[t]{3}{*}{$\mathrm{T} 5$} & 25 & $43.33 \mathrm{fg}$ & $26.67 \mathrm{k}$ & $16.67 \mathrm{j}$ \\
\hline & 50 & $33.33 \mathrm{~h}$ & 13.331 & $6.67 \mathrm{k}$ \\
\hline & 100 & $23.33 \mathrm{i}$ & $6.67 \mathrm{~m}$ & 0.001 \\
\hline
\end{tabular}

The number in the same column means followed by the same letter are not significantly different according to DMRT at 0.05 level.

*Control (water treated control), T1 (CF 75 days old), T2 (CF 60 days old), T3 (CF 45 days old), T4 (CF 30 days old) and T5 (CF 15 days old). 
alkaloids in Aspergillus nidulans. According to the database of natural products (Antibase), there are more than 39000 metabolites produced by microbes are known through their structure and chemical characteristics (Gacek and Strauss, 2012). It is known for while that many fungal secondary metabolites have been used against certain plant pathogens. For example, mycelial growth of Rhizoctonia solani was inhibited when fungitoxic secondary metabolites of Penicillium pinophilum were applied (Nicoletti et al., 2004). Antifungal activities were also reported when metabolites of Fusarium solani (endophytic fungus isolated from Taxus baccata) against Fusarium oxysporum MTCC-9622 (Tayung et al., 2010). Although, fungicidal effect of secondary metabolites of $S$. cepivorum against the same fungus is not usually explained well, the metabolites produced by a range of microbes are playing a pivotal role against certain plant pathogens through regulation of plant growth, activation of plant defense mechanisms and/or direct effect on the pathogen (Montesano et al., 2003 and Elsherbiny et al., 2015). Obtained results here in the present study suggested that culture filtrates produced at different incubation periods, decreased linear growth, number and percentage of germination of well-developed sclerotia of the fungus also, increased the mean time of sclerotia onset. That action which prevent sclerotia formation may be due to the effect of lipids and sterols accumulated in the cell membrane of $S$. cepivorum (Lucini et al., 2006).

In vivo greenhouse experiments

Effect of culture filtrates of $S$. cepivorum on disease severity

All used treatments significantly reduced the disease severity percentage in comparison with infected control treatment (Table 6 and Fig. 2) after three months and half. Data shown in Table (6) reported that there were significant differences between all used incubation periods on the disease severity done by $S$. cepivorum. Most significant results were obtained with the treatment $\mathrm{T} 5$ (treated with culture filtrate 15 days old), which gave the least value of disease severity ( $16.67 \%)$ compared with other used treatments under concentration $(100 \%)$ and infected control treatment which gave $91.67 \%$ disease severity (Table 6). The relation between disease severity percentage and each applied treatment of culture filtrates produced under different incubation periods was a strong positive relation, where $\mathrm{R}^{2}$ was 0.95 (Fig. 3). Since most of the conventional control methods are not effective, the development of eco-friendly and cost effective integrated management method is critically required. The incubation period for $S$. cepivorum to produce secondary metabolites was a very important factor during the disease control strategy using culture filtrate treatments.

TABLE 6. Effect of culture filtrates of $S$. cepivorum at different incubation periods and concentration (100\%) on disease severity of $S$. cepivorum, growth parameters, dry weight and chlorophyll a and b

\begin{tabular}{|c|c|c|c|c|c|c|c|}
\hline Treatment* & $\begin{array}{c}\begin{array}{c}\text { Disease } \\
\text { severity }\end{array} \\
(\%)\end{array}$ & $\begin{array}{l}\text { Plant } \\
\text { height } \\
\text { (cm) }\end{array}$ & $\begin{array}{l}\text { Root } \\
\text { length } \\
\text { (cm) }\end{array}$ & $\begin{array}{c}\text { Bulb } \\
\text { perimeter } \\
\text { (cm) }\end{array}$ & $\begin{array}{c}\text { Dry } \\
\text { weight } \\
\text { (gm) }\end{array}$ & $\begin{array}{c}\text { Chl. a } \\
{\left[\mu \mathrm{g}\left(\mathrm{cm}^{2}\right)^{-1}\right]}\end{array}$ & $\begin{array}{c}\text { Chl. b } \\
{\left[\mu \mathrm{g}\left(\mathrm{cm}^{2}\right)^{-1}\right]}\end{array}$ \\
\hline Healthy cont. & $0.00 \mathrm{f}$ & $62.33 \mathrm{a}$ & $23.33 \mathrm{a}$ & $9.33 \mathrm{a}$ & $19.32 \mathrm{a}$ & $61.54 \mathrm{a}$ & $34.88 \mathrm{a}$ \\
\hline Infected cont. & $91.67 \mathrm{a}$ & $24.00 \mathrm{e}$ & $5.67 \mathrm{f}$ & $3.33 \mathrm{f}$ & $4.72 \mathrm{f}$ & $30.67 \mathrm{f}$ & $11.82 \mathrm{f}$ \\
\hline $\mathrm{T} 1$ & $61.11 \mathrm{~b}$ & $36.67 \mathrm{~d}$ & $11.33 \mathrm{e}$ & $4.67 \mathrm{e}$ & $7.25 \mathrm{e}$ & $33.67 \mathrm{ef}$ & $14.53 \mathrm{ef}$ \\
\hline $\mathrm{T} 2$ & $44.45 \mathrm{c}$ & $42.67 \mathrm{c}$ & $13.33 \mathrm{~d}$ & $5.33 \mathrm{de}$ & $9.18 \mathrm{~d}$ & $36.88 \mathrm{e}$ & $17.04 \mathrm{de}$ \\
\hline $\mathrm{T} 3$ & $30.55 \mathrm{~d}$ & $43.00 \mathrm{c}$ & $14.67 \mathrm{~cd}$ & $6.00 \mathrm{~cd}$ & $12.79 \mathrm{c}$ & $43.99 \mathrm{~d}$ & $19.01 \mathrm{~d}$ \\
\hline $\mathrm{T} 4$ & $27.78 \mathrm{~d}$ & $47.67 \mathrm{c}$ & $16.33 \mathrm{c}$ & $6.33 \mathrm{c}$ & $15.04 \mathrm{~b}$ & $48.69 \mathrm{c}$ & $22.99 \mathrm{c}$ \\
\hline $\mathrm{T} 5$ & $16.67 \mathrm{e}$ & $53.33 \mathrm{~b}$ & $19.67 \mathrm{~b}$ & $7.67 \mathrm{~b}$ & $16.38 \mathrm{~b}$ & $53.62 \mathrm{~b}$ & $26.86 \mathrm{~b}$ \\
\hline
\end{tabular}

The number in the same column means followed by the same letter are not significantly different according to DMRT at 0.05 level.

*Healthy cont. (water treated control), Infected cont. (pathogen only), T1 (CF 75 days old), T2 (CF 60 days old), T3 (CF 45 days old), T4 (CF 30 days old) and T5 (CF 15 days old). 


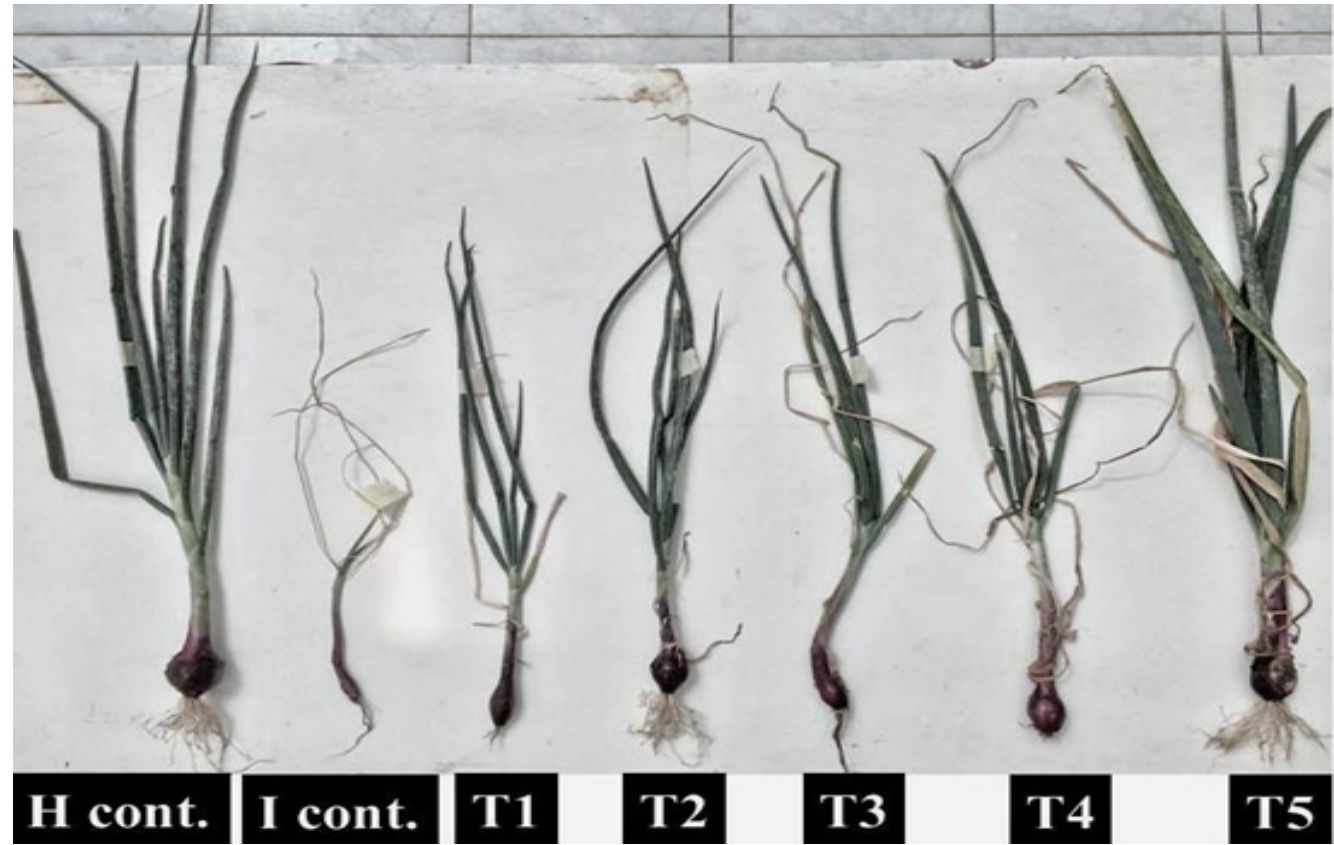

Fig. 2. Effect of culture filtrates of $S$. cepivorum under different incubation periods on disease symptoms caused by $S$. cepivorum, where: $H$ cont. (untreated control), I cont. (infected control with pathogen only), T1 (CF 75 days old), T2 (CF 60 days old), T3 (CF 45 days old), T4 (CF 30 days old) and T5 (CF 15 days old)

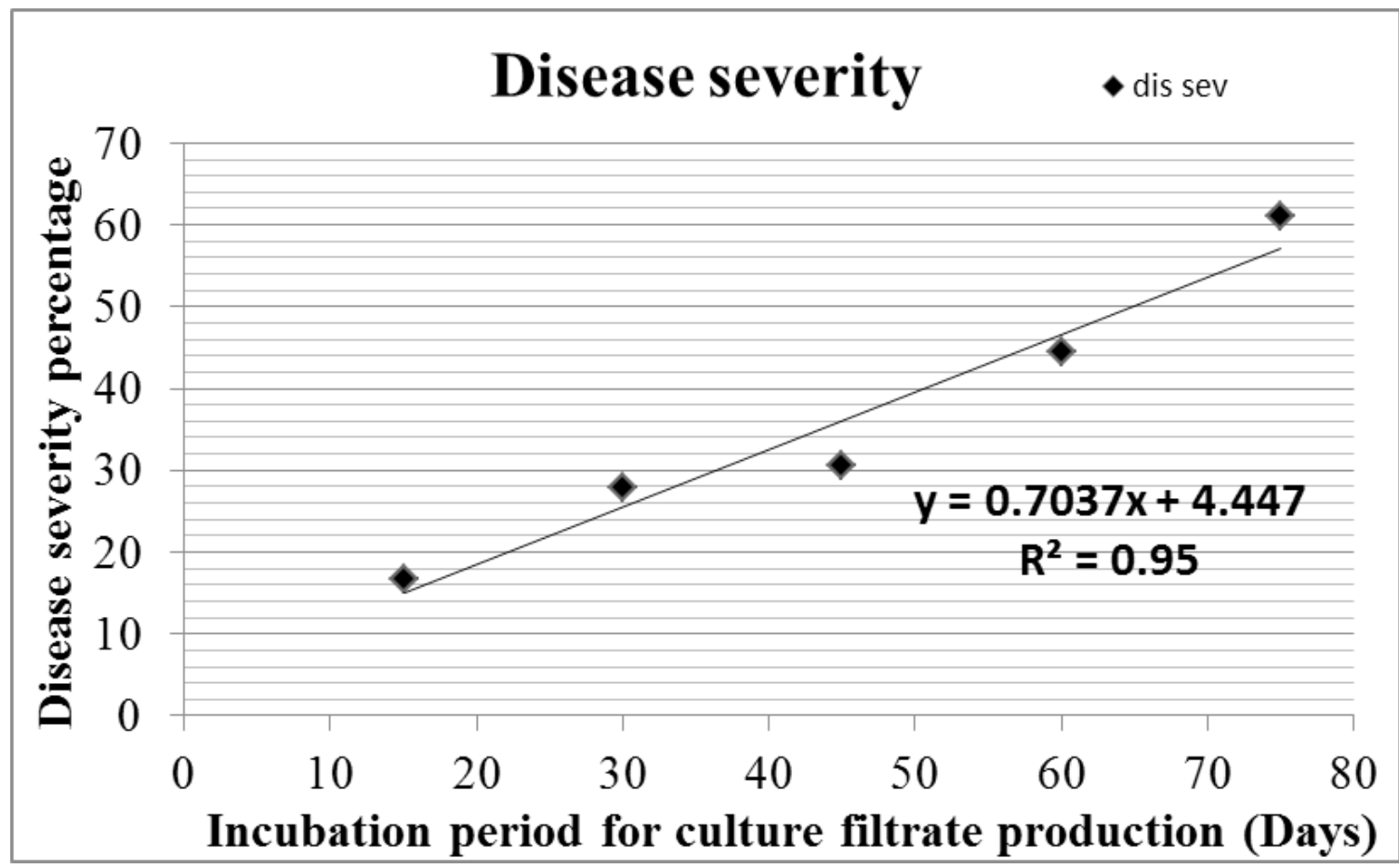

Fig. 3. Correlation $\left(R^{2}\right)$ between incubation periods needed for culture filtrate production and disease severity percentage caused by $S$. cepivorum 
Effect of culture filtrates of S. cepivorum on growth parameters

Growth parameters such as plant height, root length and bulb perimeter were also affected through used treatments (Table 6). Most significant results were obtained with the treatment $\mathrm{T} 5$ (treated with culture filtrate 15 days old), which gave the highest value of plant height $(53.33 \mathrm{~cm})$ compared with other used treatments and infected control treatment which gave $24.00 \mathrm{~cm}$ of plant height (Table 6 and Fig. 2). Obtained results showed that there were significant differences between treatments on root length. Treatment T5 gave the highest value of root length $(19.67 \mathrm{~cm})$ compared with other used treatments and infected control treatment which gave $5.67 \mathrm{~cm}$ of root length (Table 6 and Fig. 2). Bulb perimeter was also affected through used treatments (Table 6). Significant differences were found between treatments on bulb perimeter. Treatment T5 gave the highest value of bulb perimeter $(7.67 \mathrm{~cm})$ compared with other used treatments and infected control treatment which gave $3.33 \mathrm{~cm}$ of bulb perimeter (Table 6 and Fig. 2).

Dry weight and chlorophyll $a$ and $b$ content were dramatically affected by used treatments (Table 6). Obtained results showed that treatment T5 gave the highest value of dry weight and chlorophyll $a$ and $b$ content (16.38 gm, 53.62 and 26.86) respectively compared with other used treatments and infected control treatment which gave $4.72 \mathrm{~g}, 30.67$ and 11.82 , respectively (Table 6 and Fig. 2). Natural products like row cow milk or whey enhanced the plant growth parameters and yield components of treated cucumber plants against powdery mildew (Kamel et al., 2017). Applying the culture supernatants of Phoma sp. on cucumber plants were able to elicit systemic resistance against anthracnose caused by Colletotrichum orbiculare (Koike et al. 2001).
Also, foliage spraying of an aqueous suspension of Crinipellis perniciosa mycelium significantly suppressed leaf spot disease caused by Xanthomonas vesicatoria in tomato (Cavalcanti et al., 2007). Taken together, antimicrobial activities and antioxidants activities of these results suggest that the secondary metabolites investigated here could find practical application in the prevention and protection of fungal infections of plants.

Effect of culture filtrates of S. cepivorum on enzyme activities

Antioxidant enzyme activity such as peroxidase and polyphenol oxidase which considered as defensive enzymes against pathogen invasion, in treated and untreated onion plants was undertaken. Antioxidant enzyme activity of peroxidase and polyphenol oxidase were up-regulated in treated onion plants compared to other used treatments and infected control treatment (Table 7 and 8). With peroxidase enzyme activity, treatment T5 gave the highest value of $\mathrm{OD} / \mathrm{min} / 0.5 \mathrm{~g}$ fresh weight after 3 min (1.370) compared with other used treatments and infected control treatment which gave 1.041 (Table 7). Similarly, treatment T5 gave the highest value of polyphenol oxidase activity $\mathrm{OD} / \mathrm{min} / 0.5 \mathrm{~g}$ fresh weight after $3 \mathrm{~min}$ (0.354) compared with other used treatments and infected control treatment which gave 0.148 (Table 8). In addition to the antifungal activity, systemic induced resistance was also observed and reported as antioxidant enzyme activity such as peroxidase and polyphenol oxidase which considered as defensive enzymes against pathogen invasion. Data previously obtained by Ketta (2015) reported that up-regulation of antioxidant enzyme activities is closely related to the partial resistance through playing an essential act against Fusarium virguliforme infection in soybean crop.

TABLE 7. Effect of culture filtrates of $S$. cepivorum at different incubation periods on peroxidase enzyme activity: Healthy cont. (water treated control), Infected cont. (pathogen only), T1 (CF 75 days old), T2 (CF 60 days old), T3 (CF 45 days old), T4 (CF 30 days old) and T5 (CF 15 days old)

\begin{tabular}{|c|c|c|c|c|}
\hline \multirow{3}{*}{ Treatment } & \multicolumn{4}{|c|}{ Peroxidase activity } \\
\hline & \multicolumn{4}{|c|}{ Optical Density OD/min/0.5g fresh weight } \\
\hline & 0 min & $1 \mathrm{~min}$ & $2 \min$ & $3 \mathrm{~min}$ \\
\hline Healthy cont. & 1.345 & 1.390 & 1.410 & 1.420 \\
\hline Infected cont. & 0.955 & 1.000 & 1.026 & 1.041 \\
\hline $\mathrm{T} 1$ & 0997 & 1.052 & 1.082 & 1.092 \\
\hline $\mathrm{T} 2$ & 1.012 & 1.120 & 1.121 & 1.145 \\
\hline $\mathrm{T} 3$ & 1.112 & 1.135 & 1.152 & 1.170 \\
\hline $\mathrm{T} 4$ & 1.180 & 1.192 & 1.192 & 1.218 \\
\hline T5 & 1.215 & 1.280 & 1.300 & 1.370 \\
\hline
\end{tabular}


TABLE 8. Effect of culture filtrates of $S$. cepivorum at different incubation periods on polyphenol oxidase enzyme activity: Healthy cont. (water treated control), Infected cont. (pathogen only), T1 (CF 75 days old), T2 (CF 60 days old), T3 (CF 45 days old), T4 (CF 30 days old) and T5 (CF 15 days old)

Polyphenol oxidase activity

Treatment

\begin{tabular}{ccccc} 
& $\mathbf{0} \mathbf{~} \mathbf{i n}$ & $\mathbf{1} \mathbf{~}$ in & $\mathbf{2} \mathbf{~ m i n}$ & $\mathbf{3} \mathbf{~}$ in \\
\hline Healthy cont. & 0.341 & 0.377 & 0.379 & 0.380 \\
Infected cont. & 0.113 & 0.136 & 0.145 & 0.148 \\
T1 & 0.154 & 0.175 & 0.178 & 0.185 \\
T2 & 0.175 & 0.208 & 0.209 & 0.211 \\
T3 & 0.198 & 0.217 & 0.217 & 0.243 \\
T4 & 0.254 & 0.277 & 0.289 & 0.302 \\
T5 & 0.311 & 0.351 & 0.353 & 0.354 \\
\hline
\end{tabular}

Optical Density OD/min/0.5g fresh weight
Identified metabolites of S. cepivorum by $G C-M S$ analysis

Data summarized in Table 9 showed the characterization of the higher retention time 30 compounds excreted by $S$. cepivorum, based on their own retention time and peak area. The major compounds detected in the culture filtrate were categorized into alkaloids, organosilicon, antioxidants, lipids, esters, alcohols and fatty acids. The usage of culture filtrate in general was effective compared to infected control.

Saturated and unsaturated fatty acids were obtained in the present study such as, 1-Octadecene. alpha.-Octadecene Octadecylene $\left(\mathrm{C}_{18} \mathrm{H}_{36}\right)$, Octacosyl heptafluorobutyrate $\quad\left(\mathrm{C}_{32} \mathrm{H}_{57} \mathrm{~F}_{7} \mathrm{O}_{2}\right)$, Hexacosyl heptafluorobutyrate $\left(\mathrm{C}_{30} \mathrm{H}_{53} \mathrm{~F}_{7} \mathrm{O}_{2}\right)$. The antagonistic effect of culture filtrates of Bacillus chitinosporus on Pseudoperonospora cubensis the causal agent of cucumber downy mildew reported by Ketta et al. (2016) could be related to the fatty acids named hexadecanoic and n-hexadecanonic acid (n-C16) which are similar to the antifungal lipopeptide complex (fengycin A and B) produced by B. subtilis strain F-29-3 (Vanittanakom et al., 1986). The inhibitory effect and antimicrobial activity of fatty acids, excreted by bacterial bioagent, was reported (Skrrívanová et al., 2005) but the mechanism of inhibition has not been well understood.

Esters were many in this work and a lot of them have been found e.g., nonyl pentadecyl ester, Octadecanoic acid, 2-oxo-, methyl ester $\left(\mathrm{C}_{19} \mathrm{H}_{36} \mathrm{O}_{3}\right)$, 4-Hexenoic acid, 3-methyl-2,6-dioxo $\left(\mathrm{C}_{7} \mathrm{H}_{8} \mathrm{O}_{4}\right)$, Octacosyl trifluoroacetate $\left(\mathrm{C}_{30} \mathrm{H}_{57} \mathrm{~F}_{3} \mathrm{O}_{2}\right)$, Octatriacontyl pentafluoropropionate $\left(\mathrm{C}_{41}^{30} \mathrm{H}_{77} \mathrm{~F}_{5} \mathrm{O}_{2}\right)$, Hexanoic acid, 2,7-dimethyloct-7-en-5-yn-4-yl ester $\left(\mathrm{C}_{16} \mathrm{H}_{26} \mathrm{O}_{2}\right)$ and 3-Methoxy-2,4,5-trifluorobenzoic acid, eicosyl ester $\left(\mathrm{C}_{28} \mathrm{H}_{45} \mathrm{~F}_{3} \mathrm{O}_{3}\right)$. He et al. (2011) reported that fumaric acid $\left(\mathrm{C}_{28} \mathrm{H}_{52} \mathrm{O}_{4}\right)$ is one of the antibacterial components against gram-positive bacteria. Gao et al. (2017) reported that the volatile compounds such as octadecanoic acid, 4-Hexenoic acid, 3-methyl-2,6-dioxo and tert-butyl carboxylate produced by Bacillus velezensis strain ZSY-1 were very toxic volatile compounds against certain plant pathogens Alternaria solani and Botrytis cinerea. Interestingly, alkaloids which have been reported in the present study such as Tert-butyl $\left(\mathrm{C}_{15} \mathrm{H}_{23} \mathrm{NO}_{2}\right)$ was found to be the active principle compound resulting changes through cell surface architecture with reducing thickness of some pathogenic fungi (Viszwapriya et al., 2016). Lipids and lipid-like molecules such as 1-Decanol, 2-hexyl- $\left(\mathrm{C}_{16} \mathrm{H}_{34} \mathrm{O}\right)$ belonging to fatty acyls, fatty alcohols, were also reported in the present study. Cycloheptasiloxane, tetradecamethyl $\left(\mathrm{C}_{14} \mathrm{H}_{42} \mathrm{O}_{7} \mathrm{Si}_{7}\right)$ was identified previously by Jesy and Beena (2017) as antioxidant, antimicrobial and cytotoxic compounds against broad spectrum of microbes. Alcohols were also found, for example, Benzyl (dideuterated) methyl ether $\left(\mathrm{C}_{8} \mathrm{H}_{10} \mathrm{O}\right)$ and 1-Decanol, 2-hexyl- $\left(\mathrm{C}_{16} \mathrm{H}_{34} \mathrm{O}\right)$. 1-Decanol, 2-hexyl- has been identified by Swamy et al. (2017) through GC-MS and showed antioxidant and antimicrobial properties. Studies of Dehpour et al. (2012) reported that Pregnane (14-.BETA.-HPREGNA $\mathrm{C}_{21} \mathrm{H}_{36}$ ) showed antimicrobial activity against bacteria Proteus mirabilis, Enterobacter cloacae, Klebsiella pneumonia and Staphylococcus aureus. Organosiloxane (organosilicon) like Cyclotrisiloxane, hexamethyl- $\left(\mathrm{C}_{18} \mathrm{H}_{45} \mathrm{AsO}_{3} \mathrm{Si}_{3}\right)$ and Cycloheptasiloxane, tetradecamethyl $\left(\mathrm{C}_{14} \mathrm{H}_{42} \mathrm{O}_{7} \mathrm{Si}_{7}\right)$ have been found in the present study. Organosilicon and silicon in many forms have proved very effective mechanism against biotic stresses (bacteria, fungi and virus) and abiotic stresses (heat, salinity, drought, etc.) (Epstein 1994; Datnoff et al., 1997 and Savant et al., 1997). 
TABLE 9. higher retention times identified metabolites of $S$. cepivorum by GC-MS analysis

\begin{tabular}{|c|c|c|c|c|}
\hline $\begin{array}{l}\text { Peak } \\
\text { No. }\end{array}$ & $\begin{array}{c}\text { RT } \\
\text { (min) }\end{array}$ & $\begin{array}{l}\text { Area } \\
(\%)\end{array}$ & Compound & Molecular formula \\
\hline 1 & 12.949 & 0.62 & Cycloheptasiloxane, tetradecamethyl & $\mathrm{C}_{14} \mathrm{H}_{42} \mathrm{O}_{7} \mathrm{Si}_{7}$ \\
\hline 2 & 13.550 & 0.19 & Fumaric acid, nonyl pentadecyl ester & $\mathrm{C}_{28} \mathrm{H}_{52} \mathrm{O}_{4}$ \\
\hline 3 & 13.641 & 0.23 & Octadecanoic acid, 2-oxo-, methyl ester & $\mathrm{C}_{19} \mathrm{H}_{36} \mathrm{O}_{3}$ \\
\hline 4 & 14.105 & 0.71 & 4-Hexenoic acid, 3-methyl-2,6-dioxo & $\mathrm{C}_{7} \mathrm{H}_{8} \mathrm{O}_{4}$ \\
\hline 5 & 14.768 & 0.14 & Tetrapentacontane & $\mathrm{C}_{54} \mathrm{H}_{110}$ \\
\hline 6 & 15.810 & 0.37 & Benzyl (dideuterated) methyl ether & $\mathrm{C}_{8} \mathrm{H}_{10} \mathrm{O}$ \\
\hline 7 & 15.936 & 3.34 & 1-Decanol, 2-hexyl- & $\mathrm{C}_{16} \mathrm{H}_{34} \mathrm{O}$ \\
\hline 8 & 16.531 & 1.36 & 1-Octadecene.alpha.-Octadecene Octadecylene & $\mathrm{C}_{18} \mathrm{H}_{36}$ \\
\hline 9 & 16.994 & 2.85 & 14-.BETA.-H-PREGNA & $\mathrm{C}_{21} \mathrm{H}_{36}$ \\
\hline 10 & 17.378 & 3.08 & Octacosyl trifluoroacetate & $\mathrm{C}_{30} \mathrm{H}_{57} \mathrm{~F}_{3} \mathrm{O}_{2}$ \\
\hline 11 & 17.835 & 1.20 & Octatriacontyl pentafluoropropionate & $\mathrm{C}_{41} \mathrm{H}_{77} \mathrm{~F}_{5} \mathrm{O}_{2}$ \\
\hline 12 & 17.921 & 0.58 & $\begin{array}{l}\text { tert-butyl (1S,6R)-8-methyl-10-azabicyclo[4.3.1] } \\
\text { deca-3,7-diene-10-carboxylate }\end{array}$ & $\mathrm{C}_{15} \mathrm{H}_{23} \mathrm{NO}_{2}$ \\
\hline 13 & 18.019 & 0.96 & $\begin{array}{l}\text { 8.beta-(1'-Pentynyl)-3a,7a-diazatricyclo } \\
\quad[7.7 \cdot 3 \cdot 3 \cdot 0(3 a, 9 a) \cdot 0(4,7 a)] \text { dodecane }\end{array}$ & $\mathrm{C}_{41} \mathrm{H}_{49} \mathrm{IN}_{2} \mathrm{O}_{5} \mathrm{SSi}$ \\
\hline 14 & 18.774 & 1.76 & Octacosyl heptafluorobutyrate & $\mathrm{C}_{32} \mathrm{H}_{57} \mathrm{~F}_{7} \mathrm{O}_{2}$ \\
\hline 15 & 18.814 & 0.44 & Hexacosyl heptafluorobutyrate & $\mathrm{C}_{30} \mathrm{H}_{53} \mathrm{~F}_{7} \mathrm{O}_{2}$ \\
\hline 16 & 19.443 & 0.83 & Cyclohexene, 4-(4-ethylcyclohexyl) -1-pentyl- & $\mathrm{C}_{19} \mathrm{H}_{34}$ \\
\hline 17 & 20.736 & 0.88 & $\begin{array}{c}\text { 2H-Bisoxireno }[2,3: 8,8 \mathrm{a}] \text { azuleno[ }[4,5-\mathrm{b}] \text { furan-7(3aH)- } \\
\text { one, octahydro-3a, } 8 \mathrm{c} \text {-dimethyl- }\end{array}$ & $\mathrm{C}_{15} \mathrm{H}_{18} \mathrm{O}_{4}$ \\
\hline 18 & 21.206 & 1.52 & 4a,6a-Dimethyloctadecahydrochrysene & $\mathrm{C}_{20} \mathrm{H}_{34}$ \\
\hline 19 & 21.566 & 0.21 & Hexanoic acid, 2,7-dimethyloct-7-en-5-yn-4-yl ester & $\mathrm{C}_{16} \mathrm{H}_{26} \mathrm{O}_{2}$ \\
\hline 20 & 21.835 & 0.16 & 4,7-dihydro-7-imino-, ethyl ester & $\mathrm{C}_{8} \mathrm{H}_{9} \mathrm{~N}_{5} \mathrm{O}_{2}$ \\
\hline 21 & 22.379 & 0.06 & {$[1,2,4]$ Triazolo[1,5-a]pyrimidine-6-carboxylic acid } & $\mathrm{C}_{6} \mathrm{H}_{4} \mathrm{~N}_{4} \mathrm{O}_{3}$ \\
\hline 22 & 22.728 & 0.06 & 3-Methoxy-2,4,5-trifluorobenzoic acid, eicosyl ester & $\mathrm{C}_{28} \mathrm{H}_{45} \mathrm{~F}_{3} \mathrm{O}_{3}$ \\
\hline 23 & 22.980 & 0.04 & 1,2-Bis(trimethylsilyl)benzene & $\mathrm{C}_{12} \mathrm{H}_{22} \mathrm{Si}_{2}$ \\
\hline 24 & 23.317 & 0.12 & Tris(tert-butyldimethylsilyloxy)arsane & $\mathrm{C}_{18} \mathrm{H}_{45} \mathrm{AsO}_{3} \mathrm{Si}_{3}$ \\
\hline 25 & 23.420 & 0.03 & Acetamide, N-[4-(trimethylsilyl)phenyl]- & $\mathrm{C}_{11} \mathrm{H}_{17} \mathrm{NOSi}$ \\
\hline 26 & 23.752 & 0.02 & 2-Ethylacridine & $\mathrm{C}_{15} \mathrm{H}_{13} \mathrm{~N}$ \\
\hline 27 & 24.708 & 0.10 & hexamethyl- Benzo[h]quinoline & $\mathrm{C}_{32} \mathrm{H}_{32} \mathrm{~N}_{2}$ \\
\hline 28 & 24.919 & 0.10 & Tetrasiloxane, decamethyl- & $\mathrm{C}_{10} \mathrm{H}_{30} \mathrm{O}_{3} \mathrm{Si}_{4}$ \\
\hline 29 & 25.068 & 0.16 & Trimethyl[4-(2-methyl-4-oxo-2-pentyl)phenoxy]silane & $\mathrm{C}_{15} \mathrm{H}_{24} \mathrm{O}_{2} \mathrm{Si}$ \\
\hline 30 & 25.491 & 0.28 & Cyclotrisiloxane, hexamethyl- & $\mathrm{C}_{6} \mathrm{H}_{18} \mathrm{O}_{3} \mathrm{Si}_{3}$ \\
\hline
\end{tabular}




\section{Conclusion}

The incubation period needed for S. cepivorum to produce secondary metabolites was a very important factor during the onion white rot disease control strategy using culture filtrate treatments. Obtained results suggested that, culture filtrates of $S$. cepivorum at different incubation periods decreased linear growth, number and \% germination of mature sclerotia of $S$. cepivorum fungus, also increased the mean time required for the first formed sclerotia. The least value of disease severity was found with the treatment of culture filtrate 15 days old compared to infected control and other used treatments. Sclerotial germination was not observed with the treatment of culture filtrate 15 days old under concentration of 100 $\%$ for $72 \mathrm{hr}$ of soaking. Screening of secondary metabolites by GC-MS revealed 30 compounds categorized into alkaloids, organosilicon, antioxidants, lipids, esters, alcohols and fatty acids. Metabolites of S. cepivorum 15 days old could be a promising powerful and alternative way to chemical fungicides in controlling the onion white rot disease.

\section{List of Abbreviations}

GC-MS: gas chromatography-mass spectrophotometry

PDA: potato dextrose agar medium

CF: Culture filtrate

Chl.: chlorophyll

OD: Optical Density

\section{References}

Abd El-Moity, T.H. (1976) Studies on the biological control of white rot disease of onion. MSc. Dissertation, Faculty of Agric Menofia Univ., Egypt.

Abd El-Razik, A.A., Shatla, M.N., and Rushdi, M. (1973) Studies on the infection of onion plants by Sclerotium cepivorum Berk. Phytopathologische Zeitschrift, 76, 108-116.

Amselem, J., Cuomo, C. A., van Kan, J. A. L., Viaud, M., Benito, E. P. et al. (2011) Genomic analysis of the necrotrophic fungal pathogens Sclerotinia sclerotiorum and Botrytis cinerea. PLoS Genetics, 7 (8), e1002230. doi:10.1371/journal.pgen.1002230.

Anonymous (2017) Agricultural statistics. Arab Republic of Egypt, Ministry of Agriculture and Land Reclamation, Economic Affairs Sector.
Breakspear, A. and Momany, M. (2007) The first fifty microarray studies in filamentous fungi. Microbiology, 153, 7-15.

Cavalcanti, F.R., Resende, M.L.V., Carvalho, C.P.S., Silveira, J.A.G., and Oliveira, J.T.A. (2007) An aqueous suspension of Crinipellis perniciosa mycelium activates tomato defence responses against Xanthomonas vesicatoria. Crop Protection, 26, 729-738.

Coley-Smith, J.R. (1990) White rot disease of Allium: problems of soil-borne diseases microcosm. Plant Pathology, 39, 214-222.

Datnoff, L.E., Deren, C.W.; Snyder, G.H. (1997) Silicon fertilization for disease management of rice in Florida. Crop Prot., 16, 525-531.

Dehpour, A.A., Yousefian, M., Jafary Kelarijani, S.A., Koshmoo, M., Mirzanegad ,S., Mahdavi V., Mousavi S.E., Shirzad E., Afzali M., Javad Bayani M.J., Olyaei juybari E., Yahyapor M.K. (2012) Antibacterial activity and composition of essential oils of flower Allium rotundum. Adv. Environ. Biol., 6 (3), 1020-1025.

Duncan, D.B. (1955) Multiple range and multiple F-test. Biometrics, 11, 1-42.

El-Khateeb, N.M. (2004) Pathological studies on Sclerotium cepivorum the causal agent of onion white rot and its control by biological agent. M.SC. Dissertation, Agricultural Botany Dept., Faculty of Agriculture Kafr E1-Sheikh Tanta Univ Egypt.

Elsherbiny, A. Elsherbiny; Amany S. Saad; Mona G. Zaghloul and Mohamed A. El-Sheshtawi (2015) Efficiency assessment of the antifungal metabolites from Sclerotium cepivorum against onion white rot disease. Eur. J. Plant Pathol., 142, 843-854.

El-Sheshtawi, M., El-Gazzar, T., and Saad, A.S. (2009) Comparative study between chemical and nonchemical control against Sclerotium cepivorum, the causal white rot of onion under Egyptian condition. Journal of Agricultural Science Mansoura University, 34, 2169-2182.

Entwistle, A.R. (1990) Allium white rot and its control. Soil Use and Management, 6, 201-209.

Epstein, E. (1994) The anomaly of silicon in plant biology. Proc. Natl. Acad. Sci. USA, 91, 11-17.

Fox, E.M., and Howlett, B.J. (2008) Secondary metabolism: regulation and role in fungal biology. Current Opinion in Microbiology, 11, 481-487. 
Gao Z., Zhang B., Liu H., Han J., and Zhang Y. (2017) Identification of endophytic Bacillus velezensis ZSY-1 strain and antifungal activity of its volatile compounds against Alternaria solani and Botrytis cinerea. Biological Control, 105, 27-39.

He, C., Fu B., Shen H., Jiang X., and Wei X. (2011) Fumaric acid, an antibacterial component of Aloe vera L. African Journal of Biotechnology, 10 (15), 2973-2977.

Hoffmeister, D., and Keller, N. P. (2007) Natural products of filamentous fungi: enzymes, genes, and their regulation. Natural Product Reports, 24, 393-416.

Hussain, W.A. (2017) Control of onion white rot disease by using some plant extracts and Trichoderma species. Ph.D thesis, Agricultural Botany Dept., Faculty of Agriculture, Tanta University.

Ismail, I.M.K., Salama, A.M., Ali, M.I.A. and Ouf, S.A. (1990) Effect of Aspergillus terreus and Bacillus pumilus culture filtrates on Sclerotium cepivorum in vitro. Egypt. J. Microbiol., 25, 335-348.

Jayaprakashvel, M., Selvakumar, M., Srinivasan, K., Ramesh, S., and Mathivanan, N. (2010) Control of sheath blight disease in rice by thermostable secondary metabolites of Trichothecium roseum MML003. European Journal of Plant Pathology, 126, 229-239.

Jesy, E.J., Beena, J. (2017) Antioxidant, Antimicrobial and Cytotoxic Activities of Alcoholic Leaves Extracts of Spatholobus parviflorus (Roxb.Ex Dc.) Kuntze. International Journal of Pharmacognosy and Phytochemical Research, 9 (7), 1029-1034.

Kamel, S.A., Ketta, H.A. and Emeran, A.A. (2017) Efficacy of raw cow milk and whey against cucumber powdery mildew disease caused by Sphaerotheca fuliginea (Schlecht.) Pollacci under plastic house conditions. Egyptian Journal of Biological Pest Control, 27(1), 135-142.

Ketta H.A. (2015) The role of down-regulation of antioxidant enzyme activities and reactive oxygen species accumulation in playing an essential act in soybean susceptibility to Fusarium virguliforme infection. Journal of Plant Protection and Pathology, Mansoura University, 6, 1439- 1461.

Ketta, H.A., S.M. Kamel, A.M. Ismail, and Ibrahem, E.S. (2016) Control of Downy Mildew Disease of Cucumber Using Bacillus chitinosporus. Egyptian Journal of Biological Pest Control, 26 (4), 839-845.

Koike, N., Hyakumachi, M., Kageyama, K., Tsuyumu, S., and Doke, N. (2001) Induction of systemic resistance in cucumber against several diseases by plant growth promoting fungi: lignification and superoxide generation. European Journal of Plant Pathology, 107, 523-533.

Lin, H.C., Chooi, Y.H., Dhingra, S., Xu, W., Calvo, A.M., and Tang, Y. (2013) The fumagillin biosynthetic gene cluster in Aspergillus fumigatus encodes a cryptic terpene cyclase involved in the formation of beta-trans-bergamotene. Journal of the American Chemical Society, 135, 4616-4619.

Lucini, E.I., Zunino, M.P., Lopez, M.L., and Zygadlo, J.A. (2006) Effect of monoterpenes on lipid composition and sclerotial development of Sclerotium cepivorum Berk. Journal of Phytopathology, 154, 441-446.

Ma, Y., Chang, Z., Zhao, J., and Zhou, M. (2008) Antifungal activity of Penicillium striatisporum Pst1 0 and its biocontrol effect on Phytophthora root rot of chilli pepper. Biological Control, 44, 24-31.

Matta, A. and Dimond E.A. (1963) Symptoms of Fusarium wilt in relation to quantity of fungus and enzyme activity in tomato stems. Phytopathology, 53, 574-575.

Maxwell, D.P., Bateman F.D. (1967) Changes in the activities of some oxidase in extracts of Rhizoctoniainfected have been hypocotyls in relation to lesion maturation. Phytopathology, 57,132-136.

McKeen, C.D., C.C. Reilly and Pusey, P.L. (1986) Production and partial characterization of antifungal substances antagonistic to Monilinia fructicola from Bacillus subtilis. Phytopathology, 76,136-139.

Montesano, M., Brader, G., and Palva, E. T. (2003) Pathogen derived elicitors: searching for receptors in plants. Molecular Plant Pathology, 4, 73-79.

Moran, R. (1982) Formulae for determination of chlorophyllous pigments extracted with N,Ndimethylformamide. Plant Physiol., 69,1376-1381.

Mukherjee, P. K., Horwitz, B. A., and Kenerley, C. M. (2012) Secondary metabolism in Trichoderma - a genomic perspective. Microbiology, 158, 35-45.

Nattrass, R.M. (1931) The occurrence of the white rot of onion Sclerotium cepivorum Berk. in Egypt. Min. of Agric. Egypt. Tech. and Sci. Service (Plant Protect. Sect.) Bul. 107: pp. 1931). Ref.: R.A.M. 11, 219-220.

Nicoletti, R., De Stefano, M., De Stefano, S., Trincone, A., and Marziano, F. (2004) Antagonism against Rhizoctonia solani and fungitoxic metabolite 
production by some Penicillium isolates. Mycopathologia, 158, 465-474.

Pinto, C.M.F., Maffia, L.A., Casali, V.W.D., and Cardoso, A.A. (1998) In vitro effect of plant leaf extracts on mycelial growth and sclerotial germination of Sclerotium cepivorum. Journal of Phytopathology, 146, 421-425.

Saravanakumar, D., Vijayakumar, C., Kumar, N., Samiyappan, R. (2007) PGPR-induced defense responses in the tea plant against blister blight disease. Crop Prot., 26, 556-565.

Savant, N.K.; Snyder, G.H.; Datnoff, L.E. (1997) Silicon management and sustainable rice production. $A d v$. Agron., 58, 151-199.

Scharf, D. H., Heinekamp, T., and Brakhage, A. A. (2014) Human and plant fungal pathogens: the role of secondary metabolites. PLoS Pathogens, 10, e1003859. doi:10.1371/journal.ppat.1003859.

Shatla, M.N., El-Shanawy, Z., Basiony, A.M., Hanafi, A.A. (1980) Studies on Sclerotium cepivorum Berk. toxins. Menofia J. Agric Res., 3, 1-16.

Skřívanová, E., M. Marounek, G. Dlouhá and Kaňka, J. (2005) Susceptibility of Clostridium perfringens to C2-C18 fatty acids. Lett. Appl. Microbiol., 41(1), $77-81$.

Srivastava, S.K. (1987) Peroxidase and polyphenoloxidase in Brassica juncea plants infected with Macrophomina phaseolina (Tassi. Goid.) and their implication in disease resistance. Phytopathology, 120, 249-254.

Swamy, M.K. Arumugam, G., Kaur R., Ghasemzadeh A., Yusoff M.M. and Sinniah U.R. (2017) GCMS Based Metabolite Profiling, Antioxidant and Antimicrobial Properties of Different Solvent
Extracts of Malaysian Plectranthus amboinicus Leaves. Evidence-Based Complementary and Alternative Medicine, Article ID 1517683, 1-10.

Szewczyk, E., Chiang, Y. M., Oakley, C. E., Davidson, A. D.,Wang, C. C. C., and Oakley, B. R. (2008) Identification and characterization of the asperthecin gene cluster of Aspergillus nidulans. Applied and Environmental Microbiology, 74, 7607-7612.

Tayung, K., Barik, B. P., \& Jha, D. K. (2010)Antifungal activity and biocontrol potential of metabolite produced by an endophytic Fusarium (MTCC9622) against some postharvest pathogens. Journal of Agricultural Technology, 6, 409-419.

Vanittanakom, N., W. Loefller, U. Koch and Jung, G. (1986) Fengycin-A novel antifungal lipopeptide antibiotic produced by $B$. subtilis strain F-29-3. J. Antibotica, 7,888-901.

Viszwapriya, D., Prithika U., Deebika S., Balamurugan K., Pandian S.K. (2016) In vitro and in vivo antibiofilm potential of 2,4-Di-tert-butylphenol from seaweed surface associated bacterium Bacillus subtilis against group A Streptococcus. Microbiol Res., 191, 19-31.

Wiemann, P., and Keller, N.P. (2014) Strategies for mining fungal natural products. Journal of Industrial Microbiology \& Biotechnology, 41, 301-313.

Yu, J. H., and Keller, N. (2005) Regulation of secondary metabolism in filamentous fungi. Annual Review of Phytopathology, 43, 437-458.

Zewide, T., Fininsa, C., and Sakhuja, P.K. (2007) Management of white rot (Sclerotium cepivorum) of garlic using fungicides in Ethiopia. Crop Protection, 26, 856-866. 


\title{
ألمكانات المكافجة الحيوية باستخدام راشح فطر Sclerotium cepivorum ضد مرض ألعفن الابيض في البصل

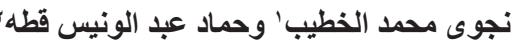

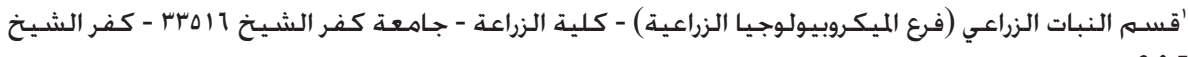

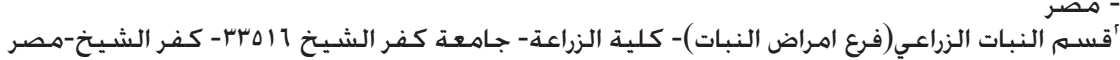

\begin{abstract}
تم اقتراح هذه الدراسـة لاختبار كفاءة راشح فطر Sclerotium cepivorum المنتج معمليا خَت فت فترات

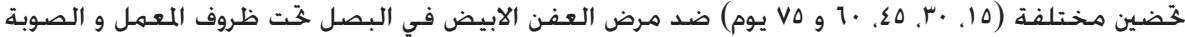

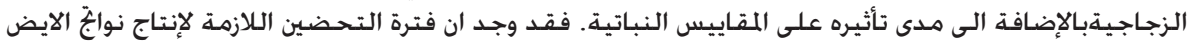

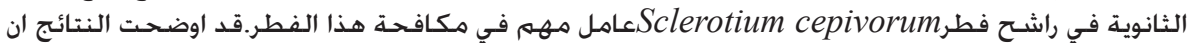

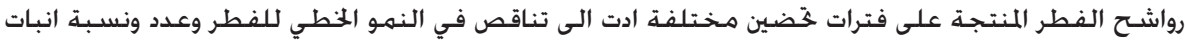

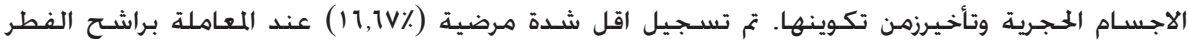

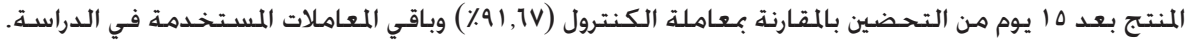

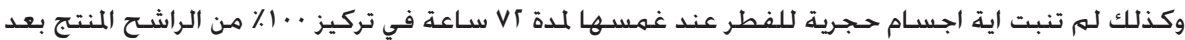

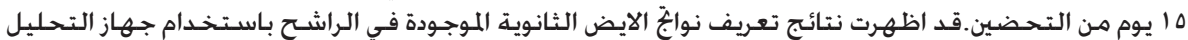

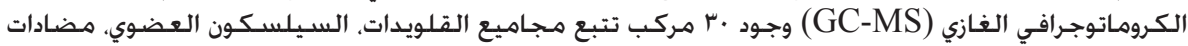

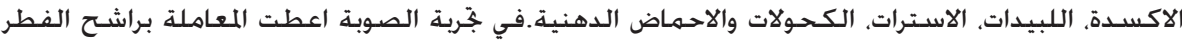

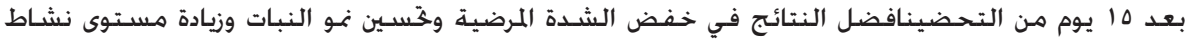

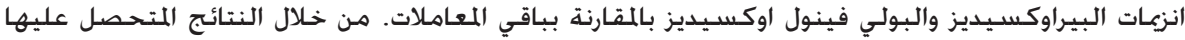

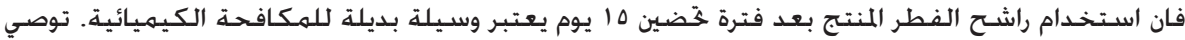

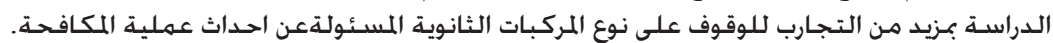

